\title{
Selecting-dismantling-assembling (Javanese culture Artifact values in modern lifestyle)
}

\author{
Susy Budi Astuti, Muhammad Faqih, Arina Hayati \\ Department of Architecture, Institute of Technology Sepuluh Nopember, Surabaya, Indonesia
}

Email address:

kreasisusy@yahoo.com (S. B. Astuti), faqih@arch.its.ac.id (M. Faqih), arina.hayati@gmail.com (A. Hayati)

\section{To cite this article:}

Susy Budi Astuti, Muhammad Faqih, Arina Hayati. Selecting-Dismantling-Assembling (Javanese Culture Artifact Values in Modern Lifestyle). Humanities and Social Sciences. Vol. 3, No. 1, 2015, pp. 18-26. doi: 10.11648/j.hss.20150301.12

\begin{abstract}
The traditional Javanese house owns reassembling wooden structure, which is done by dismantling and reestablishing it. It suits the philosophy of the Javanese family structure that a married child should settle in a new house. By detaching a part of the parents' house and reassembling it in a new location and be used by the child. This value of strong family bonding is presented in the traditional Javanese wooden house design. To bring out the Javanese house into the modern day lifestyle society, De Desa villa uses the Javanese building concept however with modern functionality. De Desa villa is chosen as a study case for having typical characteristics. Identification the background of its emergence is associated with the owner's background. Which is done by interviews. Photo documentation and field observation are done to obtain physical data. The analysis is done by linking theory, physical data and interviews. The set up process of Javanese traditional house: selecting dismantling - assembling are the main activities in realizing traditional artifact. Values and meanings are constantly present in each step of the process. Its function as a villa is expected to be appealing to the modern day lifestyle society. As explained by Rapopport (1998) that tradition does not insist to be fully accepted nor rejected. Appreciating traditional artifact does not oblique to accept the social system that it carries. It is also not necessary to reject to its value system.
\end{abstract}

Keywords: Culture, Value, Dismantling

\section{Introduction}

\subsection{Background}

House ('omah' in Javanese), for the Javanese society does not only function as a residential facility, but instead it has broader meaning. That is when its architectural values and meaning is capable in representing the activities and identity of the inhabitant. House as a process suited with the inhabitants' activities (F. C Tunner, 1972). Javanese Traditional house is a product of the Javanese culture. The typical characteristics of a traditional Javanese building can not be separated with the presence of human relation

The presence of the Javanese house in recent era has encountered dynamics. Oliver (1997) stated that often the understanding of culture is seen by the events happening while adapting with the final condition. The recent phenomena is that Javanese houses are present within the society with modern lifestyle. Although physically looking traditional, there is a start of shifting, such as the change of room's function, change in structure of organizing rooms due to different social structures, the order of a house's set up due to adapting to recent technology and resources.

There are not a lot of people who still pay attention to the presence of traditional buildings in the lives of the modern metropolitan society. If it is physically present, usually it is not followed by the process of its emerging. The characteristic of the traditional Javanese house with its wooden structures, makes dismantling and assembling possible. The system for locking joineries uses peg and pen (not nail) so it is easy to be dismantled and reassembled. It also fits the philosophy of the Javanese family structure that a married child will move out from the parents' house. The parents can give the child a few parts of the side of the building.

In holding a ceremony or an event, borrowing the house of a relative or neighbor is one of the special and unique aspects of space procurement in the traditional Javanese society. The house is dismantled (unscrew the pen / peg, dismantled and moved) and then located nearby the house of the one holding the ceremony or event. After the event is done, the house will then be returned to its owner. (Prijotomo, 2006). 
Relocating or moving the Javanese house by dismantling and reassembling it, requires to undergo a complex process. Generally the dimensions or distances of wood are not precisely the same. Which makes each joint having its own specific character. Between the 'soko' wood and blandar can't be exchanged or switched in position. Therefore lots of names of the family member are written down on every joining point of the wooden structure. In order to create a mark as a signature to ease the process of reassembling, when it is dismantled in the future. Perpetuating the names of the family member on the wooden structures of the house is a reflection of the strong family bonding within the family. Even though if someday the family member will move out and no longer reside in the residence, the names of the family member in the family structure is still recorded.

One of the obstacles in culture is the emergence of other cultures that leads to changes. This emerging of 'new culture' is brought by a new family member who just went back from having a career abroad, affects in change of values, social structure and local cultural artifact. They prefer using 'modern' materials with the modern image. This feeling of existence and pride is then brought in the form of infestation in residence. Which lead to the phenomena of people selling their traditional wooden house, but not including the land. As an exchange, a 'brick wall and ceramics' house is built upon that land. This phenomena is considered as 'such a shame' by Mr. Eko. As a person with a Javanese culture background and as a heritage observer, purchasing a Javanese house is considered as a pride for 'rescuing' the original building.

The Javanese house as a cultural artifact of the Javanese culture, is brought out in the building through a process: selecting - dismantling - assembling. The house is a process, from which the values of the traditional building will still be captured and be sensed.

De Desa vila, a wooden villa that takes the shape of the traditional Javanese wooden house. The establishing of this building which includes the process of selecting - dismantling - assembling is done and supervised by Mr. Eko as the owner. The owner understands completely that not everyone is fond of traditional atmosphere. But with the concept of family resort located in a cool area, makes this wooden villa as a unique place with a historical value of the building process, which is a form of an ongoing cultural artifact, the traditional Javanese house.

\subsection{About the Owner}

The owner is originally from Ponorogo. Coming from a modest family, with a father working as a hospital's staff and a mother working with the small family business in front of the house. A small house with 3 bedrooms, inhabited by 10 (mother, father and 8 children) makes this house very crowded and full. The available number of rooms is resolved by using the bedroom alternately and relay. This relay room organization is well accepted by the family members to show respect to the older siblings. When someone has graduated from high school and continues education outside of Ponorogo, the younger sibling will gain authority of the older sibling's room. Herewith, the sense of togetherness, respect and tolerance is introduced by the parents. With such economical condition, it does not limit them to support the children to high education. It is proven.

Often the neighbors ask whether the children can have a full stomach from everyday's meal. The mother answers: $d u d u$ wareg tapi wis cukup (not a full stomach but an enough amount). Not enough, another question is asked: Is there any home belongings sold to support the economical condition? With tearing eyes the women answered 'mboten wonten' (none). Behind the simplicity of way of life, there is a strength that should be admired, which is patience in going through anything. Like the Javanese philosophy 'Urip iku sadermo nglakoni' ( This is life is only to be gone through ).

Playing in the rice field looking for eel, swimming in the river after school, playing kites or marbles before reciting the Qur'an in the evening, is a general picture of the owner's childhood. The ability of being creative with any kind of material (without any purchasing) is actualized by creating kites and later acts as a kite 'producer' within the community of friends. Unsatisfied with his kite creation, the owner annually creates handmade Ied Fitri cards by drawing them himself. Sitting on a mat in the corner of the town square selling his Ied Fitri cards. Without really caring if anyone buy it.

As he sat on the porch with his family and siblings waiting for the maghrib prayer calling, the owner was warned by the parent "polahmu koyo ngene, ora iso lungguh anteng, senenganmu kluyuran nang sawah karo kali... gek suk gedhe pingin dadi opo ? " (Your behavior is like this, you can't be still... You like playing in the rice field and river, what do you want to be when you grow up? ). He simply answered " pokoke dadi tukang gambar...terus duwe omah cilik sawahe ombo takpageri kali" ( I want to be a craftsman who can draw, have a small house with a large rice field and surrounded by river. The parents agreed affectionately. Owning De Desa is not a coincidence, instead it has been a dream since the owner's younger years, with the parents' blessing. A small house with a humble meaning, not luxurious, with cultural nuance which suits with the owners' environment (Javanese).

Heath, Kingston Wm (2009) in 'Vernacular Architecture and Regional Design 'states that the past, personal experience affects the emotional state in the way of thinking. A big family background, a place of gathering or interaction with other family members is preferred. Although with a small house with its limit in size, the organizing of rooms occured by uniting the room function of living - dining - entertainment in one room (Saruwono, Masran, 2012).

'Mangan ora mangan asal kumpul' (Whether eating or not, what's important is togetherness), this Javanese philosophy contains a meaning that according to the Javanese tradition society bonding, especially family bonding is considered very important. But as one is able to be independent or be married, he/she must move out of the parents' house, even if they then decide to live closely.

For the Javanese society, having a house represents that one has succeeded in life. Supported by another Javanese philosophy stating that a Javanese man can be measured if he 
owns wanito is a symbol of beauty, form of goal, garwo is wife, a form of unity with the environment, wismo is a house, a symbol of shelter, turonggo is transportation, physical form, waranggono is a women singer, a form of challenge and pradonggo is gamelan, a form of serenity.

\section{Literature Study}

\subsection{Traditional Culture}

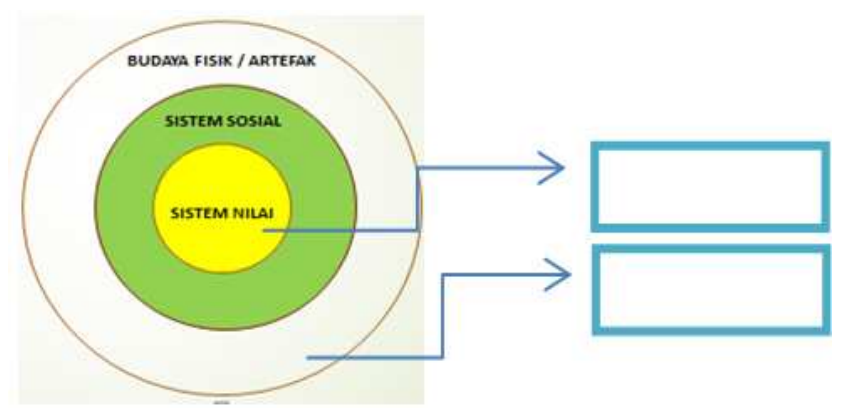

Picture 2.1. Caption for table goes at the top (source: Susy Budi Astuti)
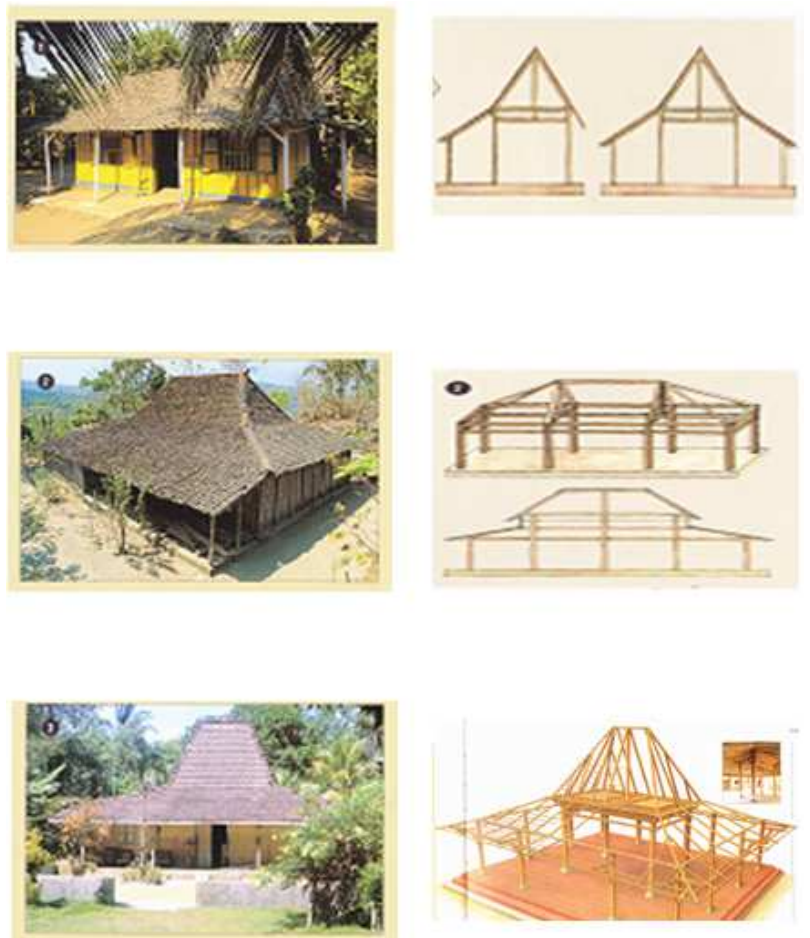

Picture 2.2. Javanese house shape (source: Gunawan Tjahyono, 1998 dalam 'Indonesia Heritage Architecture')

Rapoport (1998) in his discussion about traditional environment explains that the understanding of traditional attributes and characteristics will be different if it is related to economical, social or religious aspects. But can still be used only regarding the understanding traditional attributes. Usually and unconsciously, traditional has been related to 'out-dated' and 'the past'. This term is the antonym of the modern term and contemporary. When a traditional character is connected to the environment, the general image that is perceived is an environment that is primitive and vernacular.
Moreover explained by Rapopport that tradition does not insist to be fully accepted nor rejected. Appreciating traditional artifact does not oblige to accept the social system that it carries. It is also not necessary to reject to its value system.

According to Honigmann in Koentjaraningrat (1986), culture is categorized in definition: (1) idea, which is a notion, values or norms, rules etc. Abstract and is called cultural system which gives a boost of life to the society, (2) activities, which is an activity pattern of human in its society, social system for example activity pattern in interaction, interacting within traditional norms or code of conduct. Concrete, is called the social system, and (3) artifact, a physical form of culture such as an object and artwork. It is concrete, a physical result of the human activity/work. It can be seen and touched. Idea as a value system and activity as a social system is a cultural form in the understanding of process, while artifact is $\mathrm{a}$ in a physical form in the understanding of a real product.

\subsection{The Traditional Javanese House Form}

The traditional Javanese building which shapes according to position of the owner's status in the social system is distinguished in kampung house, limasan house, and joglo house. The kampung houses has the simplest form, it is aimed towards the common people. While the limasan house is a developed form of the kampung house, it is aimed toward people with higher social status. The joglo house is aimed for the nobles.

\subsection{House Construction}

Prijotomo, 2006 in '(Re-) Kostruksi Arsitektur Jawa' explains that the Javanese house has an assembly construction which is called "anjingan. In the anjingan technique, a stick is inserted into another stick such as a pen and its cap. Tenon from an assembled stick will be inserted into a hole inside another stick (mortise). After the tenon is inserted, the tenon is then on the top of the mortise base, meanwhile other sides of the tenon will be side by side with the sides of the mortise's hole. If the capability of creating the construction is low, it will be likely that the mortises size is larger than the tenon. As a result the assembly will not be able to attach and lock, which leads to shifting and moving. On the other hand, with excellent quality of work the risk can be reduced.

To avoid the tenon from getting off from the mortise, the tenon is made longer than the mortise hole. At this tenon stick a pen is attached, to strengthen the tenon not to get off the mortise. Any movement or shifting will not be resisted by the anjungan construction system. Instead the construction will flexibly move along with the movement.

Frick, 1997 explains that umpak (pedestal), in the Javanese house structure is not regarded as base foundation but as foot. The place where the soko or pillar is planted. Soko is not planted directly in the underground foundation, but on the umpak above the ground. The umpak structure in the construction of Javanese traditional house can be moved, which suits with the Javanese principal of a dimantleable house. 


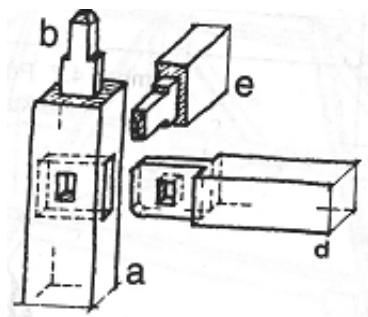

Picture 2.3. Connection technique (source: Frick,Heinz, 1997, Pola Stuktural dan teknik bangunan di Indonesia, Kanisius, Yogyakarta)

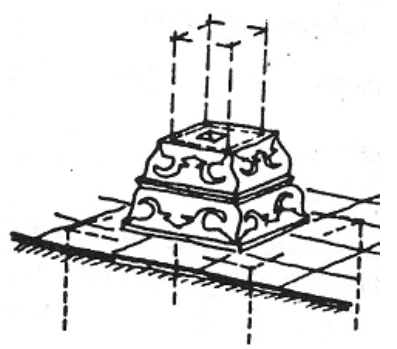

Picture 2.4. Umpak(Source: Frick,Heinz, 1997, Pola Stuktural dan teknik bangunan di Indonesia, Kanisius, Yogyakarta)

\subsection{Life style}

According to Chaney (1996), lifestyle is a manner chosen by a person or group to express themselves. Lifestyle is affected by the factors of age, religion, interaction and social mobility, education, occupation, economical condition, the use of technology, the use of time, the way of speaking or grooming. Furthermore according to Chaney, lifestyle is a way to modify new identities and is related closely to modernity.

According to Rapoport (2005), a person's lifestyle will affect his/her decisions on everything related to his/her activities. Some aspects that affect a person's lifestyle, is not only the economical factor but also how the persons uses his/her time, efforts, how the person makes use of the natural resource and how the person develops it. Finally those aspects are linked to the quality profile of his/her environment. Niit Tomaas in Arias Ernesto (1993) explains the relation between lifestyle and family. Based on psychological and sociological study, lifestyle considers the system unity between place, activity and relations. Different family composition will result in different behavior pattern.

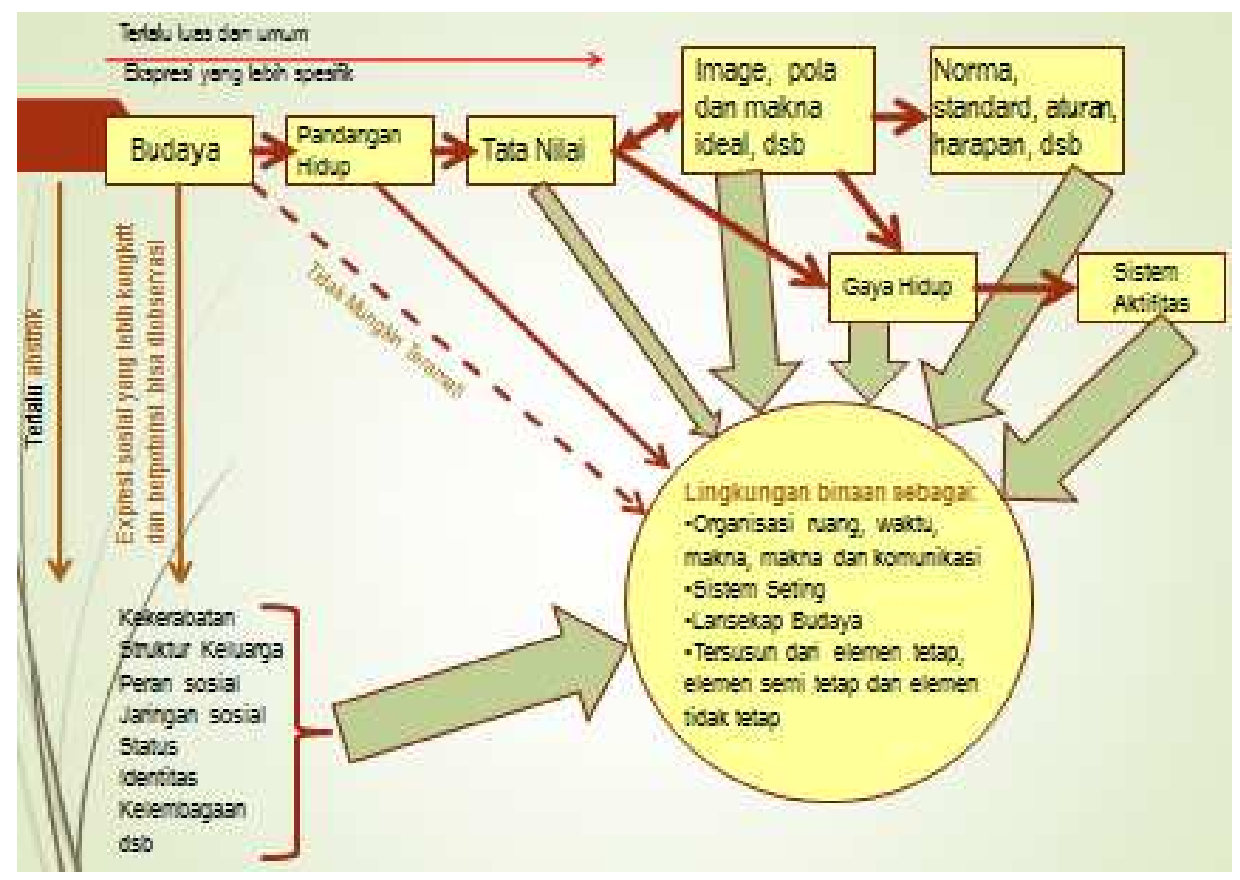

Picture 2.5. Cultural Expression (source: Rapoport. 1977 in author's private lecture notes)

In the traditional society, which still uses traditional norms, the term of lifestyle is better suited with the term of way of life. Because lifestyle is a choice. According to Bourdeau (1970) there is schema system on the formation of some specific practices (habitus) for example the difference in taste. The family environment also influences the understanding of 'taste'. Moreover according Kim Dovey (1999) interprets habitus as childhood.

\section{Research Method}

The research object is a traditional Javanese house which is obtained by Mr. Eko by dismantling and moving it from Gondang village to the recent location in Pacet, Mojokerto. This research is done to the object that has now changed in function. The object was primarily a house but it now functions as a resort (villa). The unique process of establishing the De Desa building makes it a special case. Therefore, this research uses case studies and combined strategies as the method.

Collecting supporting data is done by conducting interviews with Mr. Eko, to get his background of life that leads him to the interest of traditional Javanese house. Qualitative data include interview result notes and pictures of 
the establishing of the house. Observation to the location is done to obtain physical data of De Desa villa and also to observe the nuance of the to be related to the lifestyle. Research analysis is done by processing observation, interview and supporting data and relating it with the theory framework.

It refers to Yin in Groat-Wang, 2002, states that there are 5 characters of study cases: (1) focusing on one or several real cases, (2) the relation of cause and effect, (3) Theory development in research planning ph ase, (4) Data triangulation (Matching between theory, observation and interview), (5) Theory development.

\section{Discussion}

\subsection{The Process of Selecting the House}
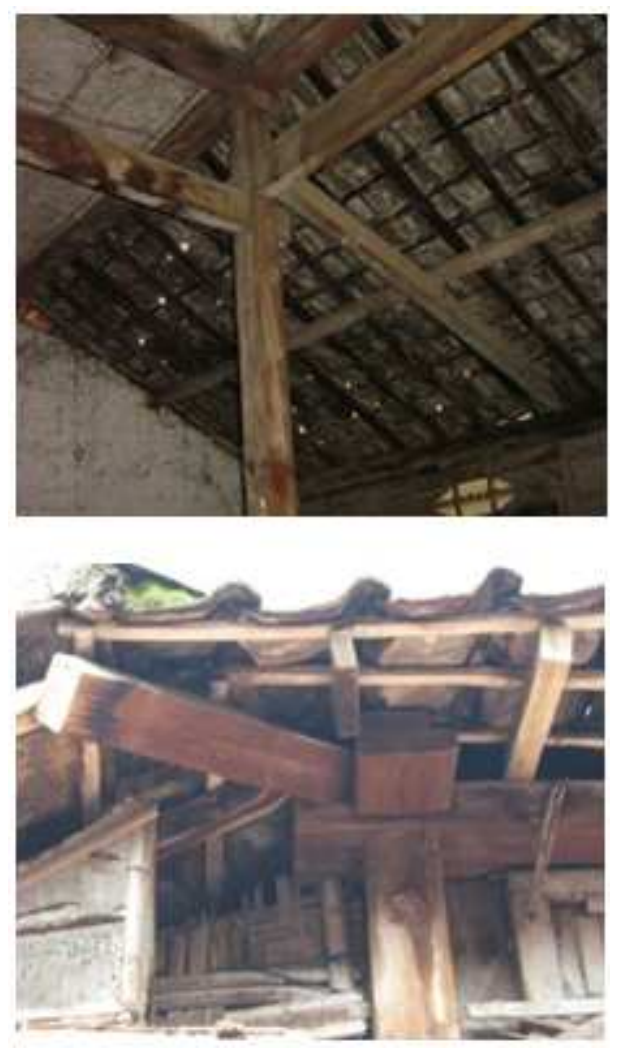

Picture 4.1. The house's original structure condition (Source: Susy Budi Astuti)

Mr. Eko fully understands about the construction structure of the Javanese house. Things to be considered in buying a traditional house are as follow:

- Full Construction, in which includes blandar's condition, tenon and mortise joint, umpak (pedestal) and pillar / soko / complete pillars with its joint structures. Old teak wood material represents the house's age and the irreplaceable historical value. The bigger the wood, the more historical value it has. Because it shows the age of the wood.

- $\quad$ Surface, which consist the wall board, the gebyok door and roof. The wall board as a surface for filling. In researching, things to be considered: gebyok door's dimension, width-height and thickness of the wooden board, the complexity of carving, shape of windows. The wooden material is old teak wood.

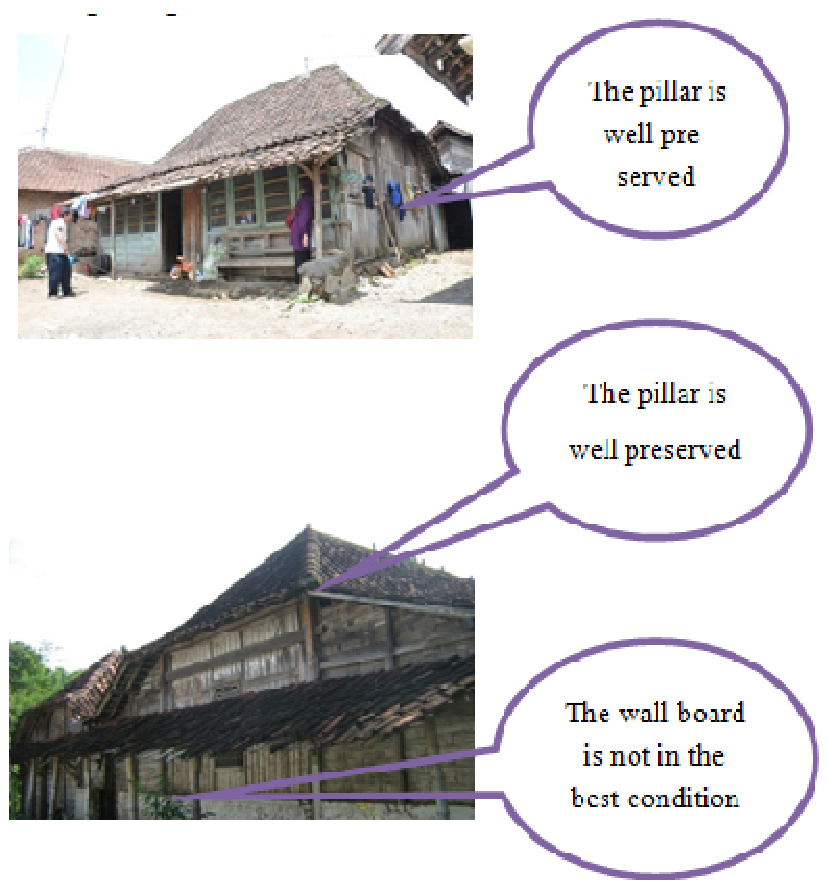

Picture 4.2. The house's original structure condition (Source: Susy Budi Astuti)

According to Rapoport ( 2005 ) meaning is cultural identity. Gondang house as a Javanese house has a stong tradisional meaning, The traditional bulding's main structure and its aesthetic elements, such as soso guru, umpak (pedestal), dodhok wesi, blandar, gebyok etc are carefully considered to pin point the 'true identity'. The bigger the wood's dimension, the older the wood's age is, which enhances the nuance of a rare old building. Rare means hard to obtain, which leads to a high cost.

Making use of something that anybody else hasn't tried and the preference to always be nearby the childhood like 'Javanase' nature (in Ponorogo) influences Mr. Eko's cognitive way of thinking. The old, outdated, 'riot' gondang house is seen to be emotional trigger for nostalgia.

\subsection{The Process of Preparing the Dismantling}

The traditional Javanese house is a handmade which leads to lots of unevenness and imperfections in dimension, position or distance. Each joint's position is not the same. To reduce the risk of error is the process of reassembling the structure components, some things need to be done beforehand:

- Coding, which is creating mark of writing on the wood, on these positions:

- Joining points, For example at the four soko guru joining points is given the code A,B,C and D. On each joining point which consist of the joining of some wood is also given a code ( A1 : soko wood, A2: blandar wood, A3: sunduk wood, etc) 


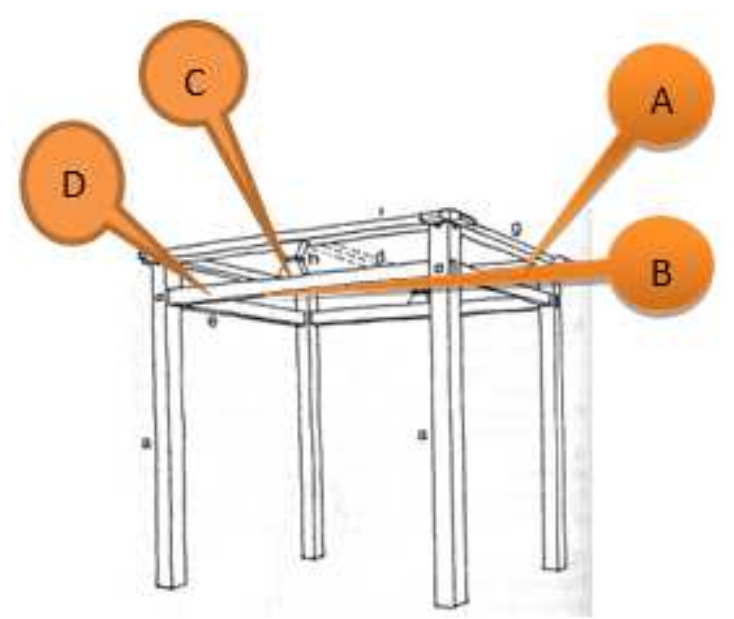

Picture 4.3. Coding Soko Guru (Source: Frick,Heinz, 1997)

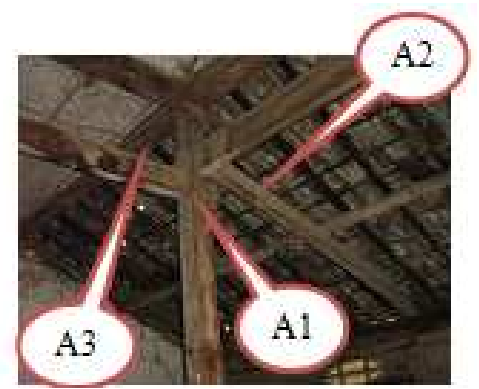

Picture 4.4. The Code's Position (Source: Frick,Heinz, 1997

Position of the Soko pilar

Pillar or soko in each position is possible to have difference in wood dimension. Each point of position needs a different treatment of work.

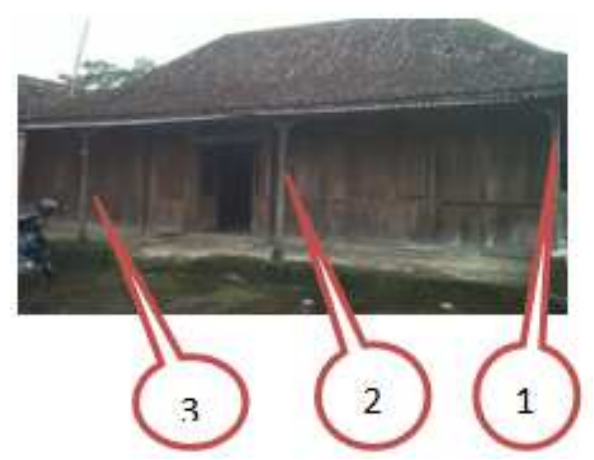

Picture 4.5. The Code's Position (Source: Susy Budi Astuti)

- Umpak's (pedestal) position

Same as the joints above the umpak. The umpak's position is also given a code.

- Measuring

The distance between the soko is not modular (the same). Therefore the distance of the length and width between the soko needs to be measured. The important part of the measuring is to prepare for the flooring base or the base on which the soko will be placed in the new location.

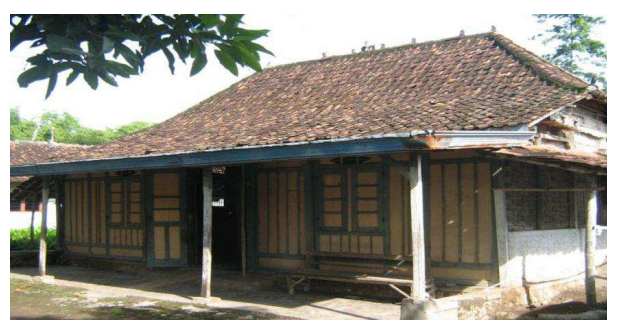

Picture 4.6. Soko Distance (Source: Susy Budi Astuti)

The preparation of dismantling include activities such as coding each joinery, measuring umpak's position and the distance between the soko is proof that traditional buildings are handmade, the craftsman of the past, which results in the variety of distance, wood dimension, umpak's dimension etc as a form of its natural environment ( Altman, 1984 ). The process of coding on each joinery points requires advanced knowledge in building structures. The house should be able to be reassembled correctly, without errors in positioning, the joinery points should be well observed in detail. Those process are a series of steps to start a special activity.

\subsection{The Process of Dismantling}

The process starts from the top then to the bottom:

- Putting down the roof tiles.

The roof tiles used is usually a village type of tile which is pretty thin in its thickness. It is not in a tight position when it is arranged next to each other. The distance of reng and usuk adapts to the roof tile's dimensions.

- Disattaching empyak

Usually empyak is cut to the width of the vehicle transporting it to the new location. Some considerations why reng and usuk is not removed one by one is to keep the joinery from being broken.

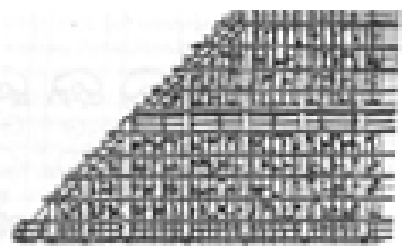

Picture 4.7. Empyak (Source: Frick,Heinz, 1997)

- Removing roof sustaining structure

- Removing blandar (belt)

- Removing pillars/soko

Before the dismantling process occurs, the wall surface materials (gebyok, wall board, windows) are taken apart in the first place.

The process of dismantling starts from the top then on to the bottom. From the building elements which acts as filling then to the structural. The knockdown system at its joints is able to tolerate any movement so that the building will not fall apart. At the dismantling process, removal of the joineries requires knowledge in dismantling with the correct structure. The person dismantling the house should have the knowledge of the traditional Javanese building structure. The person dismantling the house is originally from the area of Gondang. 
The continuity of relative bonding system and understanding of cultural artifact is an environmental value that is maintained. The environmental setting influences the setting of the activities. (Rapoport, 2005).

\subsection{The Process of Cleaning the Wood}

This process is done to bring out the character of the teak wood clearly. Generally because of the old age of the house, the wood is covered in thick dust. The cleaning process include cleaning the dirt and dust by spraying, brushing and this process also include sterilizing it from any chemical substance. It is done by cleaning the wood from paint by scraping. The step of cleaning off the paint is done before the house is reassembled to ease reaching it.

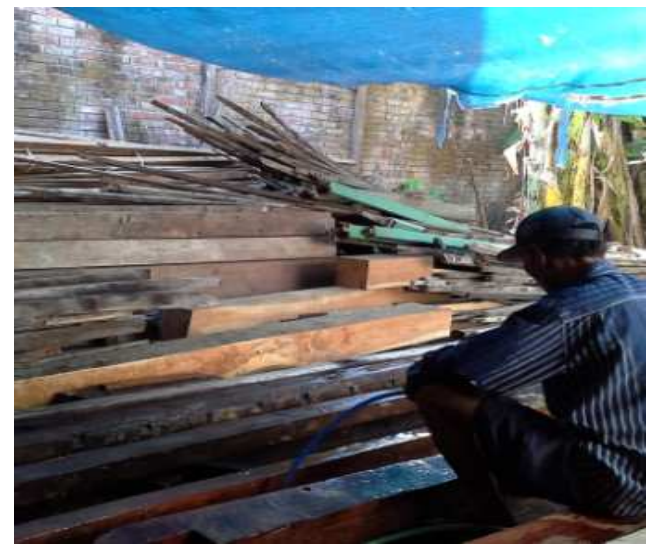

Picture 4.8. The Process wood cleaning (Source: Susy Budi Astuti)

The process of wood cleaning is done to enhance the teak wood's natural character as natural and original as it can be. No paint or synthetic finishing are added. The old material and original wooden color and texture is a regarded as pride. Sprayed, brushed and scraped are steps to 'humanize' wood as a part of the house's continuity that should be maintained and be taken care.

\subsection{The Repairing Process}

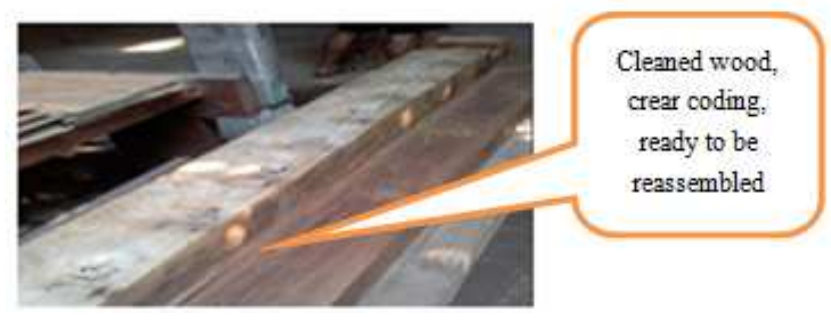

Picture 4.9. The Prepared Wood (Source: Susy Budi Astuti)

After it is cleaned, before the reassembling process, it has to be repaired beforehand. The aim of this process is to check, one of them is the joineries. If there are any hindrances as a cause of age (loose joints) it must be repaired. Some woods that are old and obsolete needs to be replaced with the same kind of old teak wood. Other than checking out the wood one by one, the process of repairing also include checking on the joinery systems. A complex process that takes a lot of time.
The workers require to have experience and knowledge in dealing with old teak wood. Usually the worker is a senior and old craftsman. Or the foreman usually has a background in working with old teak wood. Some cities with strong on going traditional Javanese culture such as Solo and Jogjakarta, have shops that offer repairing services for traditional houses.

The meaning behind the reparation process is as 'lantent function' a start of a modern living condition. By presenting it as strong, whole and guaranteed in its construction.

\subsection{The Process of Assembling}

Before the house is rebuilt / reassembled, the base should first be prepared. Because the process of dismantling starts from the top to the bottom, now the reassembling process starts from the bottom, that is by setting up the soko, then the roof. After the soko and roof structure has been set up, the surface part is set up. (Gebyok wall, wall board, doors and windows).

- Assembling soko and roof

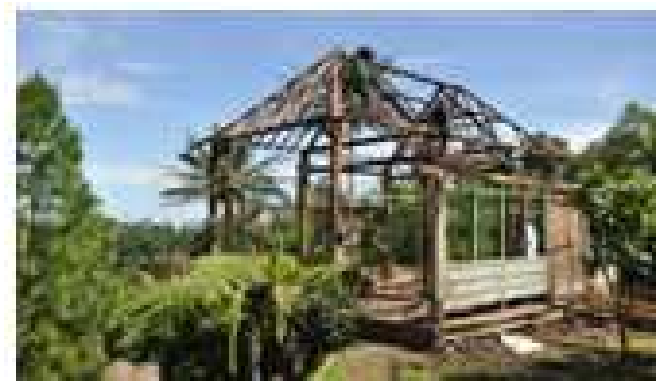

Picture 4.10. The Process of assembling soko and roof (Source: Susy Budi Astuti)

Installation of usuk and reng adapts to the roof tile's dimensions. If the roof tile is not in a good condition for usage, it will be replaced with one with the same characteristics. Which causes difference in the real reng distance. The strategy to fix it is to 'weave' between the real reng.

- Assembling the gebyok

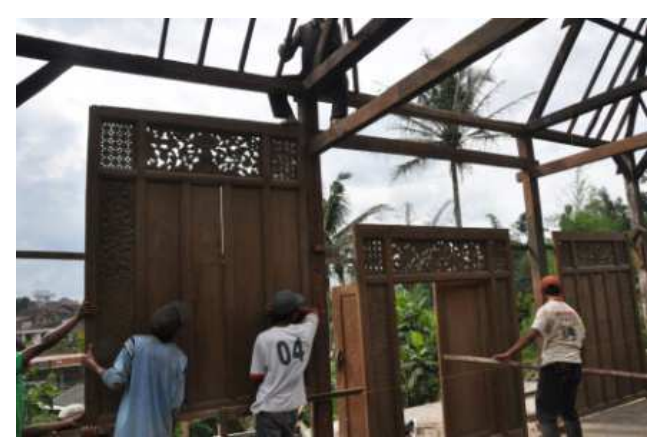

Picture 4.11. Process of surface assembling (gebyok) (Source: Susy Budi Astuti)

The process of assembling the gebyok requires attention to details and precision. Because it is a dominant element in the interior's aesthetic aspect. Artificial lighting is used to expose the gebyok in the evening. To add up a modern nuance for its artistic. 
- Assembling wall board seen from front façade

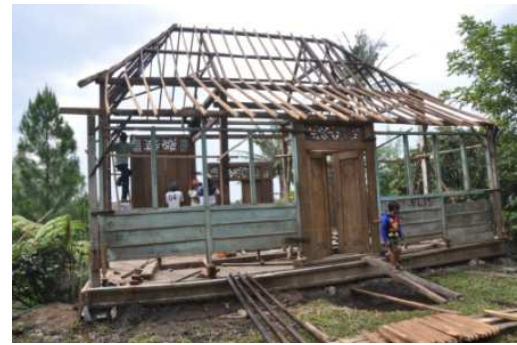

Picture 4.12. Front façade (Source: Susy Budi Astuti)

The front facade is the main appearance that should be paid attention to. Because the beauty of a Javanese house is captured from this angle. Therefore some changes are done. The front door is changed to a full carved door. The windows are also changed, a similar one with better quality, without diminishing the traditional atmosphere.

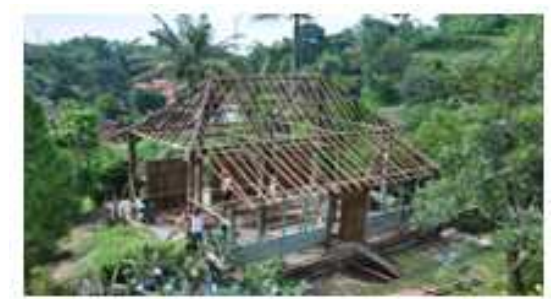

Picture 4.13. Top View (Source: Susy Budi Astuti)

- Final improvement

By giving a transparent finishing on every wood surface, the old teak wood character should still be exposed. The gap between the wallboard is regarded as a traditional local wisdom to keep the natural air circulation in the space.

Behind the simplicity of wooden traditional building of De Desa, comes with it a 'big process' of establishing. The unity with nature by locating this villa in a rice field, garden and with rivers flowing as irrigation surrounds the villa's area makes this a wonderful unity. The sound of dripping and streaming water, sounds flying birds, frogs, crickets and even geckos are not to be avoided. Even the smell of the neighbor's cow barn is swept away with the wind to the villa's area.

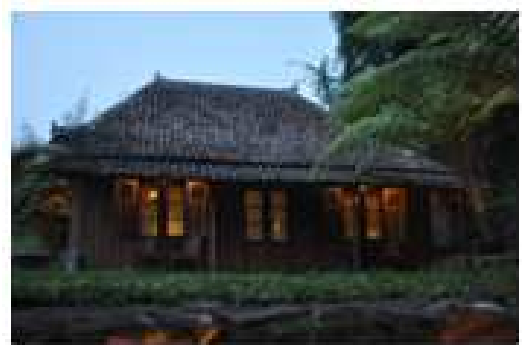

Picture 4.14. Front façade (Source: Susy Budi Astuti)

The process of assembling is done to rebuild the house to its prime condition. But due to its function as a natural resort with a temporal use, the interior elements are adapted to the user (modern lifestyle). Exposing gebyok with spot lights, the use of yellow colored lighting to create the nuance of intimacy and familiar, combining wooden furniture with modern ones, modifying antique furniture to function and look modernly etc. Physically the building and furniture still capture the traditional nuance, but the function of De desa villa is able to facilitate the lifestyle of the modern society.

\subsection{Visitor's Impression (Modern Lifestyle)}

Every guest is given the opportunity to deliver their impressions on a canvas. The impressions are as follow:

- A Hidayat, 20 April 2011

"Adhem... Ayem... Tentrem... Marem... (cold, comfortable, serene), De desa is a unity of creation and taste, creation is in the mind, Both of it should unite, unite with nature, processing the soul, be inspired, De Desa is marvelous.. "

- Priyanto, 28 April 2011

'Our heart is our real home', De desa, is a reincarnation of the owner's heart and soul. The aura of past life makes De desa encaptures the closeness of physical house and 'the real house', the soul can be felt.

- Namiko Nakamura, 30 Mei 2009

I had nice time in this villa, I hope people who will visit here will enjoy their stay like we did. Thank you.

- dr Mochtar, SpKK, 30 mei 2009

There is this intense satisfaction and happiness whenever we are able to do the impossible and then results in success afterwards. This is cool and calm place to reflect, to create further visions to be reached.

- Ir. Sugeng, 9 agustus 2009

This is the real human ark... de desa. stay here is likely \& really living with nature..., What Frank Lloyd Wright meant with this statement 'organic architecture' has to be found here..Organic means grow... grow from nature...This place is growing from and with nature..Interior growing into architecture... architecture growing into landscape... come and from landscape-architecture-interior blend into. one entity..Every human must love it..This the human real Ark.

- Indraprasti, 9 agustus 2009

America has Frank Lloyd Wright with his falling water house, India has Geofry Bawa with his lunugangga residence, Bali has Linda Garland with her Panchoran estate, Java has Eko with his de desa villa, Smart people communicating with nature through their smart home.

- Ir. Nugroho PS, 19 des 2009, Bontang

Within the life full with modern technology, staying at De desa is like a robot transforming back to an Indonesian human being. It can be an inspiration for the real life every day.

- Larasati, 19 juli 2011, Bontang The nature of java. Really open my eyes wide.

- ( Reda: Great job, creat more ), ( Faq: P eko = Guris ), (Nino: de desa aje gile ), (Teddy: de desa inspires and amazed me with its human nature side), ( Pendo: I want to learn Javanese phylosophy ), ( Rudwi: I will be back), (Evi: Great moment for us ), ( Heru: De Desa is 
very Javanese. Cool), (QQ: De Desa contains Javanese philosophy in every part and corner).

\section{Conclusion}

The family environment is the main consideration that influences lifestyle, activity system and rules within the family. (Rapoport, 2005). Simplicity in togetherness in Mr. Eko's family's small house, introduces a pattern of great tolerance. Being used to saving creates the mind set of appretiation even if it's small in value. The communication between parents and children functions as moral motivation. Limitation is not an obstacle to reach high goals. Although having reached the goals, simplicity, togetherness and respect remain in his main ideals of way of life. His Javanese nuanced childhood environment, having a background in architecture education, makes the owner a traditional Javanese architecture observer. Not only the culture, but also the process.

The process of setting up the De Desa villa is the owner's great effort. A lot of thought and energy is put into the process of 'selecting-dismantling-assembling' The house is physically treated like a living creature, the details are paid attention to, its wholesomeness maintained not to be broken, cleaned, repaired, established carefully and is taken care of. Appreciating the simplicity of a cultural artifact through understanding the values and meaning. A form of art with high level of complexity but is slightly getting worn of.

Table 1. Artifact value lifestyle in each process

\begin{tabular}{|c|c|c|c|}
\hline & Selecting & Dismantling & Assembling \\
\hline Artifact & $\begin{array}{l}\text { Wood: } \\
\text { Wood: Old teak wood, big in dimension, full } \\
\text { Structure: Soko, usuk, blandar, full and strong } \\
\text { Shape: Traditional house }\end{array}$ & $\begin{array}{l}\text { Done from the top to the bottom (from } \\
\text { the filling structure to structural) To } \\
\text { minimize the risk of breaking. }\end{array}$ & $\begin{array}{l}\text { Structure: Strong and guaranteed } \\
\text { Aesthetic: Gebyok as a dominant interior } \\
\text { element. Natural air ventilation through } \\
\text { gaps in the wall board. Natural landscape. }\end{array}$ \\
\hline Value & $\begin{array}{l}\text { Meaning of Identity of the genuine Javanese } \\
\text { cultural artifact. }\end{array}$ & $\begin{array}{l}\text { All the dimensions and structures are not } \\
\text { in precision and modular, because it is } \\
\text { handmade. } \\
\text { Precious in originality, because it shows } \\
\text { the high culture and civilization. }\end{array}$ & $\begin{array}{l}\text { The greatest process in dismantling is the } \\
\text { togetherness and teamwork in every point } \\
\text { of wood assembling. Not every craftsman } \\
\text { are able to do such process. Mr Eko plays a } \\
\text { major role as the leader. }\end{array}$ \\
\hline Lifestyle & $\begin{array}{l}\text { The eagerness always be close to the Javanese } \\
\text { culture by 'rescuing' the Javanese house. Jawa }\end{array}$ & $\begin{array}{l}\text { The process is done by including } \\
\text { craftsman and hand-in-hand work. } \\
\text { Trying to build connection and unity } \\
\text { with the environment. }\end{array}$ & $\begin{array}{l}\text { Introducing a traditional Javanese house to } \\
\text { the modern lifestyle society by modifying } \\
\text { its function to a villa. It is physically in a } \\
\text { traditional shape, but its room organization } \\
\text { and interior can be enjoyed and functions } \\
\text { according to the modern day lifestyle. }\end{array}$ \\
\hline
\end{tabular}

\section{References}

[1] Chaney, David, 1996, Lifestyle Sebuah Pengantar Komprehensif, Jalasutra, Bandung.

[2] Dovey, Kim, 1999, Framing Places, Mediating Power in Build Form, Routledge, Lond.

[3] Frick, Heinz, 1997, Pola Stuktural dan teknik bangunan di Indonesia, Kanisius, Yogyakarta.

[4] Koentjaraningrat, 2005, Pengantar Antropologi 1, Rineka Cipta, Jakarta.
[5] Prijotomo,Josef, 2006, (Re) Konstruksi Arsitektur Jawa, PT. Wastu Lanas Grafika, Surabaya.

[6] Koentjaraningrat, 2005, Pengantar Antropologi 1, Rineka Cipta, Jakarta.

[7] Rapoport,Amos, 2005, Culture Architecture and Design, Locke Science Publishing Company, USA.

[8] Rapoport,Amos, 1994, Sustainability Meaning And Traditional Environment in Traditional Dwellings And Settlements Working Paper Series, Vol.75/IASTE 75-94, Center for Environmental Design Research, California. 